\title{
Teaching the Rules of a Free-market Economy in Post-Communist Countries - Metroeducation Case in Poland
}

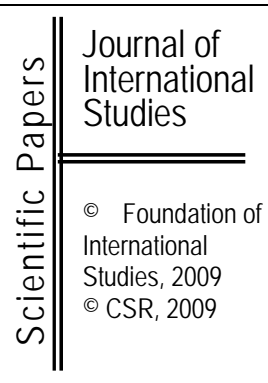

\author{
PhD Waldemar Rydzak \\ PhD Jacek Trębecki \\ Department of Economic Journalism \\ and Public Relations \\ Poznan University of Economics \\ Al. Niepodleglości 10/324B, 61-875 Poznañ \\ waldemar.rydzak@ue.poznan.pl \\ jacek.trebecki@ue.poznan.pl
}

\begin{abstract}
The emerging of large, international trading corporations in Poland has been a natural consequence of the changes in the country's political system. However, foreign companies that invested in Poland had to face unusual problems. On the one hand, they were teaching Polish society the rules of a free-market economy but, on the other hand, there was a strong conviction in people's mindset that these corporations' intentions were not good and that it was dangerous for Polish merchants and producers to cooperate with them. One of the first companies that noticed the problem and began working on a coherent program dealing with corporate social responsibility was the German corporation called METRO Group. A program appropriate for the needs of the Polish market was to combine educational, image-oriented and political goals.
\end{abstract} Submitted: January, 2009 $1^{\text {st }}$ revision: April, 2009 Accepted: June, 2009

Keywords:

Social Responsibility, Communication, Education, Public Relations

JEL classification: M14, D83, A2, P1

\section{Introduction}

The emergence of large international trading corporations on the Polish economic scene was a natural consequence of social and political transformations. Yet, the foreign companies that arrived in Poland faced a number of unusual challenges. On the one hand, they taught the public the principles of the free market, on the other, they had to deal with the common perception of evil multinationals that are out to jeopardise the business of Polish merchants and manufacturers. One of the first enterprises to recognize the problem and launch a consistent effort of social responsibility in business was METRO Group of Germany (Rydzak \& Trebecki, 2005). 
The effectiveness and efficiency of traditional PR strategies, which were successful in developed countries, may be rather low in transition countries. In the late 1990s, failure of several international network agencies (e.g. Burson-Marsteller) and their temporary withdrawal from the Polish market was a rather evident consequence of the fact that this specificity had not been taken into account in business plans. Developing social acceptance of the new system requires the traditional PR perspective to be extended to include additional elements.

\section{Figure 1. The sources of transition public relations}

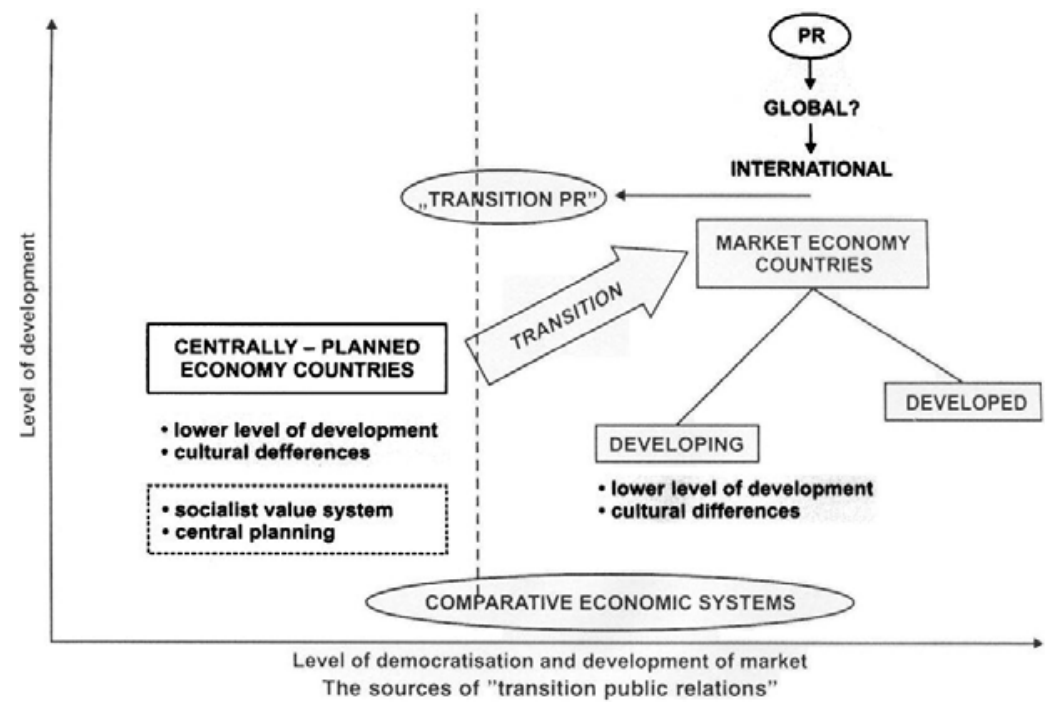

Source: (Lawniczak, 2001)

According to a Polish business organization- BCC- Corporate Social Responsibility (CSR) should be treated as a strategy saying that a company voluntarily takes social interests into consideration while aiming to achieve economic goals. According to this, CSR suggests taking ethical interests, the rights of employees, human rights, the social and natural environment into account. Corporate Social Responsibility should be, apart from the economic aims of a company, an integral policy of a corporation (bcc, 2005).

However, Responsible Corporation Forum treats this concept a little differently, stating that CSR is a strategy of management minimizing the risks and maximizing success over a long period of time through increasing positive input of the corporation into society and also through treating members of the marketing process, cooperation, employees or clients in a specific way (Forum Odpowiedzialnego Biznesu, 2008). In this case CSR becomes not so much a strategic element of management but a concept that reduces the sensitivity of a company towards social risks.

\section{The use of CSR tools}

Porter differentiates four areas in which social activity of a company strengthens the competition context of a company's activity. These are the production conditions, the strategic and competitive conditions, factors supporting demand and branches that support a corporation and are connected with it.

Conditions supporting production include the characteristics of production factors: work force or infrastructure. These factors consist of competence, education and motivation of employees, the quality of road or teleinformation infrastructure. A company can have an impact on improvement of part of these factors by investing in educational programmes, 
supporting the activity of local governments which care for or enforce the care of infrastructure. What mainly directs the social activity which supports production are programs increasing employees' competence, changing their attitude towards work or motivation system.

Strategic or competitive conditions mainly consist of the clarity and predictability of political economic decisions, the fight against corruption and nepotism, the abiding by the laws of intelectual property. Improving these conditions mainly means supporting social programs and campaigns or organizations promoting certain attitudes.

Factors shaping local demand are mostly connected with marketing activity strengthening product and brand awareness and generating the willingness to obtain and use a certain solution. An important role, however, is played by social activity and campaigns. An example of such activity are the campaigns of pharmaceutical or hygiene products companies, which stress the necessity to use certain products or solutions.

Companies producing sports clothes and shoes are guided by similar premises by taking an active part in events promoting sport as an alternative form of lifestyle among youth. Nevertheless, factors strengthening demand may also include a wider activity promoting certain democratic values, overcoming ideological barriers enabling the free exchange of thoughts or ideas.

Branches supportive of and connected with a corporation, the development of which determines the success of a company, make up the last factor. An example could be the correlation between the development of tourism and an interest in credit cards, which tourist companies offering travelling credit cards, have discovered. It is natural that companies aware of that correlation will support tourism development and promote active rest. In the same way, the development of a cell phone operator on the local market will become a natural opportunity for a cell phone producer.

Thus, CSR campaigns may be a strategic element in creating advantageous conditions for the functioning of a corporation. However, negative experience in implementing similar programs may cause barriers in use of CSR tools. Scientists at St. Gallen Institute of Leadership and Personnel Management studied the causes of such experiences (Bruch \& Frank, 2005). The study carried out on the management of seven large corporations and a few small companies became the basis of their observations. As a result, they identified the main mistakes characterized by the focus of the corporations on two approaches towards social involvement. It is either a market orientation or competence orientation. The first approach is connected with a detailed analysis of local societies' needs and involvement depending on social expectations. In this way a company is trying to fulfil social needs believing that it will improve its position on the market and make its relations with authorities or other cooperators easier. Programs of such activity are often created without much thinking and considering the strategic needs of a company.

This lack of connection with the company's needs often results from the specifics of the appropriate departments, which are often separated out as a foundation or funds from the corporation's structures. Such subjects have their own budget and strong autonomy in implementing their own set of goals. They can carry out projects that are extremely important for the local societies such as educational programs, charities or integration programs. However, the lack of connection with the strategic goals of the company causes the fact that the only result from the corporation's point of view is the sense of fulfilling social responsibility. Thus, such programs become the first victim of a savings policy, budget cuts or changes in a company's leadership.

The second approach focuses on competence. The basis of such approach is an assumption that a company can implement its social mission in the best way in areas where its highest competence is, resulting from staff experience, equipment that they have or know- 
how. According to this assumption, counselling companies help social organizations free of charge, the equipment producers give out specialist tools, and pharmaceutical companies create examination or prevention programs. The strong point of such approach is an engagement of genuine, often unique and valuable competence of the company. The enthusiasm of employees, their sense of unity and mission can also become the driving force of that sort of programs.

However, the weak point of this approach is the fact that beneficiaries' expectations may not go together with what the companies might be offering them. This kind of problem may, in turn, transform into unwillingness towards the donor's company and blaming it for trying to achieve their own goals.

\section{The global dimension of METRO Group}

METRO Group is one of the largest and most international retailing companies worldwide. Some 270,000 employees from 150 nations work at around 2,400 outlets in 30 countries in Europe, Africa and Asia. The portfolio of its strong sales brands offers a wide range of services for private and commercial customers. The group has a clear portfolio: METRO AG stands at the top as a strategic management holding company. The operative business is divided into business segments of wholesale, food retail, non-food specialty stores and department stores. Under the wings of the METRO Group, a shared corporate culture has emerged, creating an identity-providing code of values that extends across business segments.

METRO Group has been present in Poland since the mid-nineties, where it has four sales brands: Makro Cash and Carry, Real, Praktiker and Media Markt. The company itself is a trading market leader in Poland, having 108 large selling space hypermarkets altogether. METRO Group is also the biggest employer in its brand, employing about 25200 workers. The corporation comes in fifth place among the biggest Polish companies and, at the same time, it is also the biggest private corporation in Poland.

\section{Political and economic background}

In the eighties Poland was part of a political block with a centralized state economy which excluded not only foreign companies but also private ones from taking part in economic circulation. In 1989 the first non-communist government and it's Minister of Finance Leszek Balcerowicz, established a set of legislative changes under. The majority of the society welcomed the free-market economy with hope and enthusiasm. The new reality was fascinating and appealing. Shop windows were becoming full of goods and private companies were being set up. The stock exchange was a determinant of economic activity. Its first session took place on April 16th 1991. It noted the shares of five companies. In 1996 the capitalisation of stock, that is the worth of all shares present in transactions, exceeded 20 billion zloty (about 5 billion Euro). In May 2004 there were over 200 companies with a worth exceeding 190 billion zloty (GPW, 2003).

The first shock that Poland experienced was a crisis connected with the breakdown of trade with the East. It turned out that one can also lose on the stock-market and that companies collapse. Capitalism showed its dangerous side.

The end of the nineties in Poland was characterized by the fact that enthusiasm and social acceptance towards political transition was beginning to fade. General elections, during which left-wing parties were supported, was the result of this. One could notice that politicians of that time, but more and more often the media as well, were ill-disposed towards foreign companies, and especially towards the expansion of foreign capital. According to a group of politicians foreign investement did not leave any production values- warehouses, 
production plants, investing only in trade, which had a big effect on the Polish economy. In addition, people started to report that their working conditions were harsh, that they could not get promoted or that they faced strict discipline. There has been a significant crisis in the image-oriented free market activity (Lawniczak, 2001).

Large selling space hypermarkets also faced these sort of problems. They were set up in the mid-nineties, and they offered quality that had not been known in the Polish trade so far- a lot of choice and advantageous prices. However, both the representatives of smaller trade companies and some politians, who were protecting the home trade, did not like the competition that had appeared on the Polish market. Another factor was the fact that local governments were reluctant towards foreign companies as well and in fear of losing support of the society they started to proclaim populist slogans. The next argument, besides the national one and the one protecting smaller traders, was saying that the employees' rights were abused. Moreover, there was a suspicion of dumping or low prices meaning low a quality of the products (CBOS, 2006).

\section{Premises of the program implementation}

At the beginning of 1999 the representatives of METRO Group board came to the conclusion that one cannot think about long-term foreign expansion unless the lack of social trust and negative stereotypes are overcome.

The original ideas assumed that there was a need for a communicative program, which would be connected with the area of environment protection or culture. However, the analysis carried out by the Public Relations agency showed that the only complex solution would be a strategic program which would allow to build a corporate image that is socially responsible, but also it would make companies more transparent, friendly and closer to local communities.

After different options had been discussed, it was accepted that all expectations may be best met by a program based on education, in which young people were to be involved, preferably pupils. The main idea of METROeducation project was set up in half a year.

The Polish government's plans that were supposed to improve the structure of the Polish education system became the direct impulse in creating METROeducation (MEN, 2003). It turned out that Polish trade secondary schools' learning programs were not adequate for the needs of the modern Polish job market, especially for the new types of institutions such as hypermarkets or department stores. Besides just knowledge, the methodology of teaching also seemed insufficient. Classes were held in a traditional way, with a lessonoriented schedule, and particular subjects were not synchronized with both internship and vice verca. Schools were clearly not invested in and, at the same time, education was thought to be one of the most important areas (CBOS, Czy Polacy cenia wyksztalcenie - komunikat z badan, 2002). In these circumstances the idea of supporting Polish trade secondary school education appeared. METRO Group decided to share part of its organizational and trade experience in order to offer Polish pupils the opportunity to get this sort of experience.

\section{The concept of the program}

The point of the program was the fact that METRO subcontracted some specialized units to come up with a special program, based on already existing ones, to educate young traders. The programme was facilitated with teaching materials, document samples, video films, etc. In addition, pupils had the opportunity to go through a two-month-internship in METRO Group sales outlets.

Then, a few schools from the cities where METRO institutions were placed were chosen and offered to be part of the program. Each school received already prepared lesson plans, 
teaching curriculums and aids, videos, etc. Besides that, METRO trained the teachers and let pupils do their internship in hypermarkets. Having finished the education process, students could take a special exam and when passed it received the certificate which confirmed their participation in the program.

In agreement with the Polish authorities, the program which was prepared in an appropriate way and availabe for the chosen schools (trade or technical secondary schools) was introduced to pupils in their third year of learning in a particular school. The structure of the changes enabled to classify the programme as 'innovation' totally integrated with the Polish trade schools' curriculum of those days.

The main assumption of the changes was to enrich the knowledge that pupils gained with some practical elements connected with the specifics of trade in large selling space hypermarkets. These elements were introduced by both coming up with the programs of pupil training in METRO depots and supporting modern teaching techniques based on computer software, simulation classes, practical lessons using the equipment and software needed in big depots, etc.

This sort of program implementation completed certain tasks:

- It made the corporation's contact with the country's authorities possible. Before implementing the project three authority institutions were contacted. The program was kindly supported by the Polish president. The reason why it was so accepted was the fact that the program was in agreement with the idea of corporate social responsibility promoted by the president and his wife in order to invest in Polish youth. Before introducing the program at schools it had to be and was supported by a number of Polish ministers of education. The program was a confirmation for each minister that their ideas of educational changes were right, paying particular attention to the needs of the job market, making learning process in Poland more practical and working according to the educational standards of the European Union. The third, less formal but as important, authority institution that approved of the program and supported it was the Curia of the Primate of Poland. The Curia's approval was gained by the support of a few Catholic schools that were financially supported by the Church. Thanks to such varied institutions that supported the program (the left-wing president, Church authorities and the Ministry of Education with a political attitude dependent on the configuration of the Parliament of that time) while talking to the local governments an investor had arguments to lead a discussion from every political point of view.

- It made it possible to bring the METRO network hypermarket into existence in the awareness of local authorities. The first opportunity was an initial conversation during which the authority representatives were informed about both the program with the active institution and the willingness to help a school. An authority representative designated a particular school, which made them partly emotionally attached to the program. After that, authority representatives received an annual report about how the program was being implemented, they were also invited to the inauguration of the school year, to graduation and sometimes even to exams.

- It made it possible to set up institutions for Polish local societies. Each year about sixty students took part in the project in each of the fourteen cities involved. Every year the pupils spent about two months in a supermarket learning about the procedures of its functioning, taking part in the supermarket's life, observing not only the place where goods were sold but also the warehouses and social background. Pupils became a transmission line dispelling many myths about what is going on in the supermarket. Their observations concerning the fact that the quality and also hygiene procedures were strictly followed were made known to their parents and local societies as well. 
What they reported was even more trustworthy because of the fact that they were not employed by the corporation and so they did not have to be afraid of anything and besides that they were not suspected of hiding the truth.

- Establishing close contact with the school. An unchanging team of teachers was cooperating with supermarket representatives within the framework of the program. This cooperation was not only a simple coordination of internship but according to the program's assumptions the teachers were learning 'the supermarket' as well. They were being aquainted with the procedures of the supermarket chain, given the documentation samples, book-keeping programs, etc. During the training sessions the teachers were exchanging their opinions with the supermarket employees and receiving from them (future employers) information about supermarket's expectations and based on these expectations they could modify the teaching material. Later the teachers were able to pass this knowledge on to the students who did not take part in the program. In this way a single teacher could reach even a few thousand pupils from a particular school. Thus, such a teacher was becoming a multiplier of positive corporate image.

- It made it possible to establish contacts with the local media. Each event such as: an exam, graduation, etc. was accompanied by the fact that journalists were invited to come and then they could report about the program on a larger scale. Journalists were invited by both a local representative of METRO institution and also by the school's principal. On the one hand, it facilitated the position of a local manager and, on the other, it made it possible to have a journalist at such a non-commercial event.

\section{Implementation of the program}

In September 2000 the program began to be implemented in particular schools. Teachers from these schools also took part in three training sessions as an aid for the experts from the German Training Center in Retailing.

Figure 1.

\section{Structure of project management (simplified scheme)}

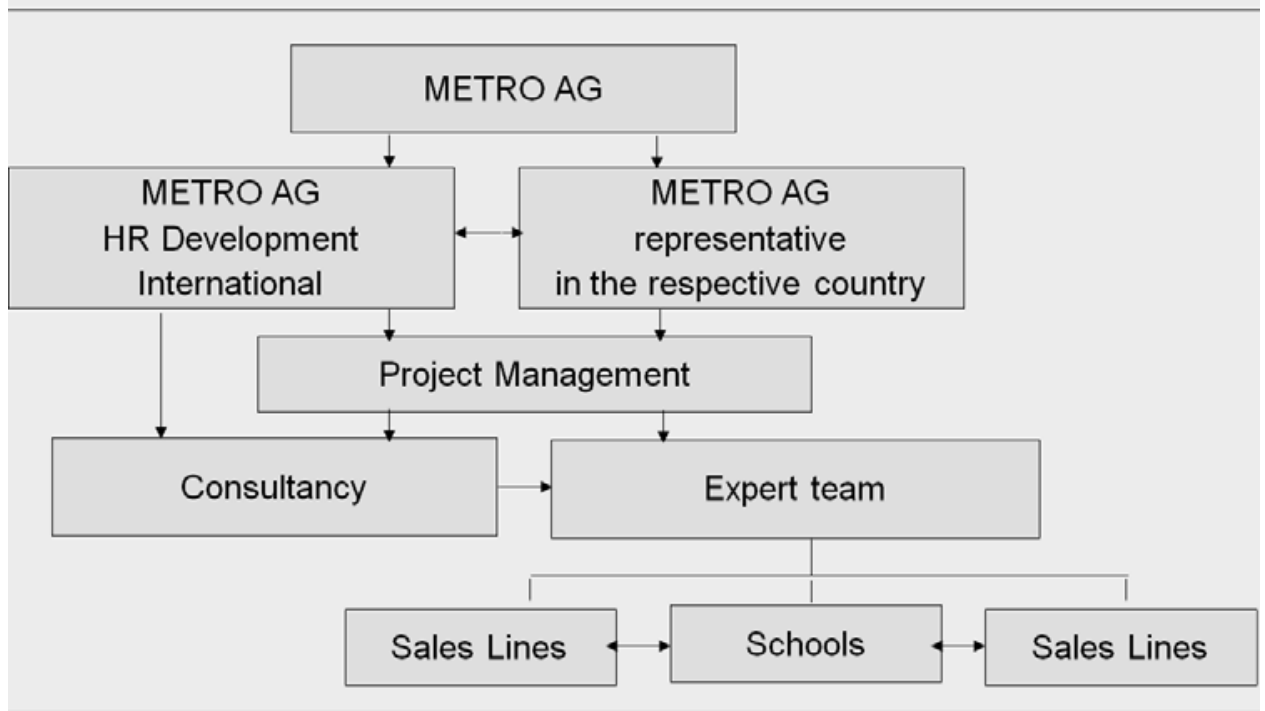

Source: (Schneuwly, 2003) 
The third-graders who took part in the project were working according to a special curriculum and they were also doing their internship in the stores of a METRO AG chain. Moreover, some teaching sessions were led by market experts. The knowledge of the students who took part in the first edition of the program was verified by a professional exam that they had to take in May 2001. The exam took place around the hypermarket where the students had to do some practical tasks concerning consumer service, product research, advertising, accounting and the like.

In the meantime more schools were being ivolved in the project and in January 2002 the second edition of the program started. 178 pupils from trading schools in such cities as: Warszawa, Poznan, Lodz, Zabrze, Kilece and Czestochowa, took part in it.

In September 2002 first-graders from trading secondary schools in Poznan and Warszawa and then since 2003 from Lublin and Gdansk as well started taking part in the program.

The next schools which started implementing the program in January 2004 were the schools from Czeladz, Krakow, Gdansk and Lublin.

The teaching curriculum was prepared by specialists in collaboration with the experts from the Trading Education Center (BZE) in Neu Konigsaue. Its implementation was directed in agreement with the representatives of particular METRO outlets and stores which are situated in the same place where the pilot program was held.

During the implementation, based on different teacher's observations and new opportunities, modules concerning the European Union were developed. Part of the teaching material was taught in German and, what is the most important, pupils had the opportunity to go to Germany for their internship and the pupil who would graduate with the best results would get a university scholarship in Germany.

The observations of the program's implementation brought a few corrections. One of the largest problems was a big rotation in managing staff of particular hypermarkets. Actually, each promotion was followed by transferring the employees to new outlets. The person substituting the previous manager had to learn the whole program from the beginning. What often happened was also the fact that the former manager had taken all the materials, curriculum and internship timetables with him/her while leaving. Thus, in order to create an easily available and simple resource of information a virtual educational platform called METROeducation was built. All of the materials concernig the program (videos, teaching aids, internship curriculum, etc.) were collected in one server and one could easily obtain whatever information was needed by simply entering one Internet page and typing the password.

Besides that, all evaluation procedures were also transferred to the Internet. The most important ones were the evaluation forms which students, teachers, hypermarket managers filled in in order to assess the program and share some suggestions about its further functioning. This sort of evaluation form was filled in twice a year. What is more, there was a discussion group that was functioning and if someone had a serious problem there was the possibility of entering an Internet chat room. Such Internet contacts were one way of organizing some help for the students who were less affluent, for example pay for their health examination or allow them to work in a hypermaket part-time. This Internet page was one of the first such sites in Poland.

A few additional enterprises were also held. There were three situations when the best students of the program were able to go for a few-week-internship to Germany and one of the most talented students was sponsored to go for a four-year-scholarship to a German university. 


\section{The effects of the campaign implementation}

During the seven years of implementation (2000-2006) the program turned out to be the biggest enterprise of that sort in Poland. Its effects were so encouraging for the corporations that the program implementaion was also started in countries like Russia, Romania, China and Croatia.

From a corporation's point of view the campaign had a strategic dimension. During its implementaion it was possible to combine the marketing approach (in which while choosing the target groups and the areas of activity the attention that society pays to education was also considered) with the competence approach because the METRO Group chose the area in which it had a highly competent staff and it could be of real support.

Figure 2. New pupil ability $(\mathrm{n}=157)$

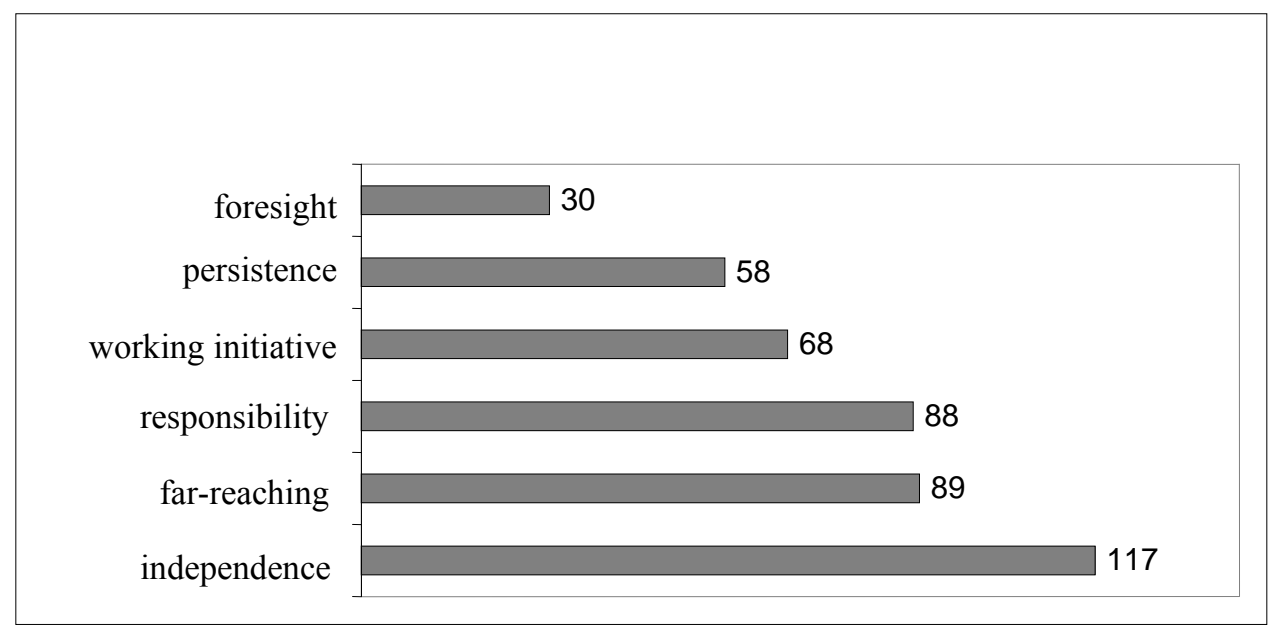

Source: An analysis by the authors based on own surveys

What is more, the program's implementation has changed the context of the competition in the company's activity and also supported the corporate image. Out of the factors that support the competitive context of the corporation the factors shaping the demand were most emphasized. During the seven years of the program's implementation tens of thousands of people found out about the program but, most of all, about the corporation's way of functioning from different beneficiaries, teachers, through the distribution of materials, visits on the web site about the project, etc. These were mostly people recruiting themselves from the local societies. Thanks to the information it was possible to communicate about the social activity of the corporation, but, first of all, to facilitate the brand awareness and prove that the doubts about the corporation's way of functioning and about the quality of goods were unnecessary.

As far as strategic and competitive factors are concerned, the knowledge about the expectations that a large selling space hypermarket has towards its suppliers and employees, was strengthened.

As far as the facilitation of the competitive context a significant thing was the creation of a base of well-qualified employees. According to the survey of the program's beneficiaries which was carried out during the project's implementation it turned out that over $75 \%$ and, in some cases, up to $90 \%$ of the pupils wanted to continue their education. However, only about $15 \%$ of the pupils took up work at the hypermarket, thus strengthening its team.

Corporate image activities were usually held apart from the media. They mostly 
consisted of establishing contacts with the central and local authorities. It even seems symbolic that in October 2004, exactly at the same time when the corporations of the trading competition were struggling with losses (such as Biedronka, part of the portuguese Jeronimo Martens corporation, or the french network Intermarche), the polish president, Aleksander Kwaśniewski welcomed the representatives of the METRO Group in the presidential palace in Warsaw with great honours.

\section{REFERENCES:}

1. Bruch, H., \& Frank, W., (2005, Fall), The Keys to Rethinking Corporate Philantrophy, MIT Sloan Management Rewiev, pp. 49-55

2. CBOS, (2002), Czy Polacy cenia wyksztalcenie - komunikat z badań, Warszawa: CBOS

3. CBOS, (2006), Kapital zagraniczny w Polsce - komunikat $\mathrm{z}$ badań, Warsaw: CBOS

4. Club, B. C., (2005), Business Center Club, http://www.bcc.org.pl, 27 Januar 2009

5. Forum Odpowiedzialnego Biznesu, (2008), http://www.fob.org.pl, 02 Februar 2009

6. Giełda Papierów Wartościowych, (2003), http://www.gpw.com.pl/gpw.asp2cel=ogieldzie, 14 May 2008

7. Lawniczak, R., (2001). Transition Public Relations-an instrument for systemic transformation in Central and Eastern Europe, in: R. Lawniczak, Public Relations cotribution to transition in Central and Eastern Europe, Poznan: Printer

8. Ministerstwo Edukacji Narodowej, (2003), http://www.men.gov.pl, 20 September 2008

9. Rydzak, W., \& Trebecki, J., (2005), Metroeducation's social responsibility programme: from distrust to approval, The Lisbon Congress PR, Lisbon, pp. 227-239

10. Schneuwly, J. P. (20), Vision for an International Vocational Retail Training Programme, Poznan, Wielkopolska, Polska: Company Strategy and HR Development International - Metro AG. 